\title{
Influența detașării frunzelor asupra acurateței măsurării unor parametri fotosintetici la aninul verde
}

\section{A. Popa}

\section{Introducere}

Fotosinteza este unul dintre procesele de bază care condiționează creșterea, acumularea biomasei, dar și procesele competiționale (Pallardy 2008). Măsurarea schimbului de gaze dintre plantă și mediul extern are o importanţă majoră în înţelegerea procesului fotosintetic (Cavaleri et al. 2015, Verryckt et al. 2020), respectiv în
Popa, A. 2020. The influence of leaf detachment on the accuracy of measuring photosynthetic parameters of green alder. Bucov. For. 20(2): 119-126

Abstract. Photosynthesis is the most basic activity in plants and is very important for many processes such as growth, biomass allocation, competition processes. Measuring leaf gas exchange from canopy leaves is a difficult task because of tree height and impossibility to carry the equipment at canopy level. This study tested the possibility to measure gas exchange on detached leaves, on leaves attached to detached branch and on leaves attached to detached branch but placed in a container with water immediately after the detachment. The species on which the study was conducted was green alder (Alnus viridis (Chaix) DC.) because of the accessible height and its importance on mountain ecosystems. In the first two situations because of water deficit at leaf level, a decrease was found for net assimilation (A), water loss (E), stomatal conductance (gsw) soon after the detachment. In the third situation when the branch was placed in a water container there were no significant change in photosynthetic processes, parameters were maintained at over $80 \%$ form initial value.

Keywords: photosynthesis, gas exchange, green alder, leaf detachment, branch cutting.

Author. Andrei Popa (popa_andrei_dorna@yahoo.com), National Institute for Research and Development in Forestry "Marin Drăcea", Câmpulung Moldovenesc Station, Calea Bucovinei 73 bis, 725100 Câmpulung Moldovenesc, Suceava; "Ștefan cel Mare" University of Suceava, Faculty of Forestry, 13 Universității, 720229 Suceava, Romania.

Manuscript received September 16, 2020; revised November 20, 2020; accepted December 04, 2020; online first December 08, 2020. 
ne dificilă (Meng și Arp 1992, Meng et al. 2019, Verryckt et al. 2020), fiind condiționată de deplasarea şi instalarea aparatelor şi instrumentelor necesare. Pentru realizarea măsurătorilor in situ, la nivelul coronamentului, la arbori cu înălțimi de peste $2 \mathrm{~m}$, sunt necesare construcții auxiliare de tipul turnurilor, a platformelor speciale sau diferite tipuri de scări prin care să se permită accesul la nivelul coronamentului, implicând un efort și costuri suplimentare, de multe ori nejustificate (Tang şi Wang 2011, Gauthier și Jacobs 2018). Cercetările realizate în aceste condiții, cu amenajări suplimentare, sunt relativ reduse (Nakamura et al. 2017), și sunt condiționate de existența în prealabil a structurilor sau constructiilor necesare. Studiile de fiziologie la specii de arbori sau arbuști în condiții extreme sunt limitate, adeseori, din cauza inaccesibilităţii: distanţa mare de la drumul auto, pantă ridicată, teren accidentat. O soluție pentru a depăşi aceste restricții este ca materialul biologic să fie detașat din coroana arborilor sau din locul în care vegetează în mod natural specia și să se realizeze măsurătorile în laborator, la baza arborilor (la nivelul solului) sau unde pot fi montate instrumentele necesare în condiții de siguranță. Cercetările experimentale au evidențiat modificări ale schimbului de gaze la nivelul frunzei în momentul în care s-a secționat pețiolul (Mitchell et al. 1999, Gauthier și Jacobs 2018) sau la frunze ce au rămas atașate de ramuri, dar care au fost secționate, fiind introduse sau nu în apă (Tang și Wang 2011, Meng et al. 2019, Verryckt et al. 2020). Majoritatea studiilor au vizat modificări în reacția materialului biologic prelevat din coronamentul arborilor și mai puțin la nivelul arbuștilor.

Aninul verde (Alnus viridis (Chaix) DC.) este o specie care apare frecvent în ecosistemele alpine și subalpine, cu un rol ridicat în stabilizarea versanților, în prevenirea eroziunii, dar și la formarea solului prin descompunerea rapidă a litierei, având capacității ridicate de stocare a azotului în sol (Anthelme et al. 2002; Boscutti et al. 2014). Pentru această specie nu s-au realizat studii de fiziologie, astfel, prin intermediul cercetărilor curente, se pot obține informații 120 importante privind procesele fotosintetice.

Obiectivul acestui studiu este de a analiza rata de modificare a parametrilor de caracterizare a procesului fotosintetic pentru aninul verde în 3 situații diferite care implică detașarea frunzei de planta mamă: frunza individuală, frunza ataşată de un lujer secţionat și frunza ataşată de un lujer secționat și introdus în apă. Ipotezele testate sunt: deficitul de apă din frunză indus prin întreruperea sistemului de circulație a sevei dintre frunză și lujer are un efect direct și rapid asupra asimilației nete (A), conductanței stomatale (gsw) și transpirației (E); introducerea lujerului secționat în apă diminuează semnificativ modificarea majoră a principalilor parametri de caracterizare a fotosintezei (A, gsw, E).

\section{Material și metodă de lucru}

Cercetările s-au efectuat în cadrul Parcului Naţional Călimani $\left(47^{\circ} 7^{\prime} 8^{\prime \prime} \mathrm{N}\right.$ și $25^{\circ} 13^{\prime} 46^{\prime \prime}$ 'E), într-o zonă cu impact antropic redus, la altitudinea de 1720 metri. În zona de studiu specia dominantă este aninul verde (Alnus viridis (Chaix) DC.) fiind prezente exemplare de molid (Picea abies (L.) Karst), zâmbru (Pinus cembra L.), scoruş (Sorbus aucuparia L.), jneapăn (Pinus mugo Turra), dar și numeroase specii de arbuști: afin (Vaccinium myrtillus L.), merișor (Vaccinium vitis-idaea L.), smârdar (Rhododendron myrtifolium).

Rata de modificare a fotosintezei a fost analizată în 3 cazuri experimentale distincte: frunza detaşată de planta mamă prin tăierea pețiolului (6 frunze de la exemplare diferite); frunză atașată de un lujer tăiat la o lungime de 20 centimetri ( 5 frunze de la exemplare diferite); frunză atașată de un lujer tăiat la o lungime de 20 centimetri şi introdus imediat într-un recipient cu apă (4 frunze de la exemplare diferite). Mărimea eșantionului a fost condiționată de durata mare de efectuare a măsurătorilor și asigurarea unui număr minim de înregistrări.

Măsurătorile experimentale s-au realizat în luna august 2019, moment în care aparatul foliar era complet dezvoltat. Schimbul de gaze 
a fost măsurat cu ajutorul echipamentului LI-COR 6800, după îndeplinirea condițiilor de stabilitate, urmând un protocol bine definit (Covshoff 2018). Prin atașarea unei frunze în camera de măsurare, acesta este supusă unor condiții de mediu controlate (temperatură, umiditate, concentrație de dioxid de carbon și intensitate a luminii), din acest motiv este necesar să se acorde un timp frunzei pentru a se adapta. În momentul în care abaterea standard a valorilor măsurate (concentrația $\mathrm{CO}_{2}$ și $\mathrm{H}_{2} \mathrm{O}$ ) în ultimele 15 secunde are valori sub 0,1 se consideră că s-au îndeplinit condițiile de stabilitate și se pot realiza măsurători. În cazul experimentelor realizate parametri constanți în camera de măsurare au fost următorii: concentraţia de $\mathrm{CO}_{2} 1000 \mu \mathrm{mol} \cdot \mathrm{mol}^{-1}$, intensitatea luminii $1200 \mu \mathrm{mol} \cdot \mathrm{m}^{-2} \cdot \mathrm{s}^{-1}$, temperatura de $23^{\circ} \mathrm{C}$ și umiditatea relativă de $60 \%$. Analiza ratei de modificare a parametrilor fotosintezei a avut drept referință măsurătorile realizate în condiții in vivo (fără întreruperea legăturii dintre frunză și planta mamă) pentru un interval de 5 minute.

Parametrii măsurați au fost: asimilația netă (A), transpirația (E), conductanța stomatală (gsw), măsurătorile efectuându-se la interval de 30 secunde, cu o durată maximă a monitorizării de 55 minute. Pe baza parametrilor măsurați au fost calculați 3 parametri derivați de caracterizare a fotosintezei: eficiența utilizării apei (WUE), eficiența intrinsecă a utilizării apei (iWUE) și eficiența carboxilării (A/Ci) (Marozas et al. 2019).

Analiza statistică și testarea diferențelor între diferite momente s-au realizat prin analiza varianței unifactorială ANOVA și a testului posthoc Tukey (Abdi și Williams 1993). Prelucrarea datelor, analiza statistică și realizarea graficelor S-a realizat în cadrul programului RStudio folosind limbajul de programare $\mathrm{R}$.

\section{Rezultate}

Variația parametrilor măsurați în cadrul schimbului de gaze pe durata de referință, respectiv cât timp frunza este ataşată de lujer, rămâne relativ constantă. În urma detașării frunzei de planta mamă s-a observat un răspuns prin scăderea ratei asimilației nete, a transpirației, dar și a conductanței stomatale (figura 1). Dintre cele 3 situații analizate în cazul frunzei detașate s-a constatat cea mai rapidă și ridicată reducere. Asimilația a scăzut la $75 \%$ din valoarea de referință la 3 minute din momentul în care s-a întrerupt legătura cu planta, iar conductanța stomatală și transpirația ajung la aproximativ $60 \%$ după același interval de timp. După scurgerea a 10 minute din momentul detaşării de planta mamă asimilația ajunge la 50\%, în timp ce conductanța stomatală și transpirația scad până la $35 \%$ din valoarea inițială, măsurată înainte de întreruperea legăturii. Parametrii monitorizați scad sub $15 \%$ din valoarea iniţială după 20 minute din momentul secționării pețiolului. Eficiența carboxilării (A/Ci) urmează un trend de variaţie similar cu cel al asimilației fiind direct proporțională cu aceasta. Din punctul de vedere al eficienței utilizării apei (WUE) și eficienței intrinsecă a utilizării apei (iWUE) se observă o variaţie lineară până la momentul detașării, ulterior constatându-se o creștere până în jurul valorii de 150\% în cazul iWUE și $120 \%$ pentru WUE.

Pentru a limita efectul întreruperii legăturii frunzei cu planta, s-a analizat situația în care frunza a rămas atașată de lujerul ce a fost secționat, în două variante: introdus sau nu în apă. În situația în care lujerul nu a fost introdus în apă s-a observat o rată de reducere a parametrilor de caracterizare a procesului fotosintetic similară cu cea din cazul frunzei detașate. Scăderea valorilor parametrilor măsurați (A, E, gsw), comparativ cu valoarea de referință, a înregistrat un ritm mai redus de scădere decât în situaţia frunzei detaşate. Scăderea parametrilor măsurați sub $15 \%$ din valorile de referință s-a atins după 35 de minute de la secționarea lujerului.

În cea de a doua situaţie lujerul detaşat a fost introdus imediat într-un recipient cu apă în vederea compensării circulației sevei brute. Asimilația netă în acest caz rămâne la valori de peste $80 \%$ din valoarea de referință. 

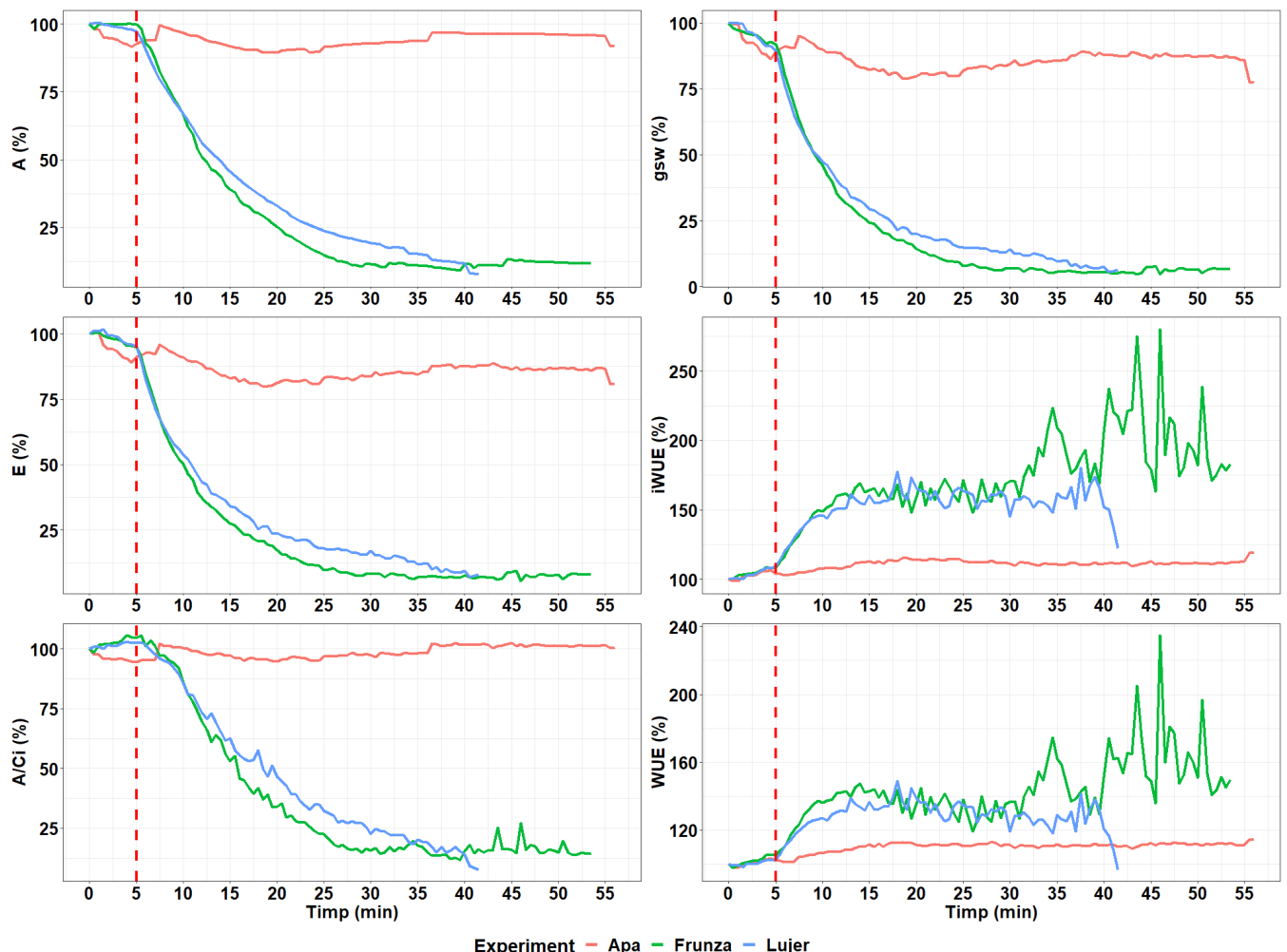

Figura 1 Rata de modificare a parametrilor de caracterizare a fotosintezei (în procente) în raport cu timpul pentru cele 3 variante analizate (frunza detaşată, lujerul detașat și lujerul detaşat introdus în apă). Cu linie punctată roșie s-a marcat momentul în care s-a întrerupt legătura frunzei cu planta.

The change rate of the photosyntesis parameters (as a percentage) in relation to the time for the 3 analyzed cases (detached leaf, detached shoot and detached shoot introduced into water). The red dotted line marked the moment of leaf detachement.

Conductanța stomatală și transpirația au înregistrat o reducere lentă în primele 10 minute, după care s-au stabilizat la valori cuprinse între $75-85 \%$ din valoarea inițială. Parametrii derivați nu au înregistrat variații semnificative, doar în cazul eficienței utilizării apei şi eficienței intrinsecă a utilizării apei fiind înregistrate creșteri cu 10-20\% față de valoarea de referință.

Pentru stabilirea momentului în care modificările survenite în cadrul proceselor fiziologice diferă semnificativ statistic $(p<0,05)$ față de valoarea de referință (fără întreruperea legăturii dintre frunză și planta mamă - momentul $\mathrm{t}=1$ minut) s-a efectuat analiza varianței (ANOVA) și s-a aplicat testul Tukey. Rezultatele obținute sunt prezentate în figura 2.

Pentru asimilaţia netă în cazul frunzei cu pețiolul tăiat și a lujerului tăiat fără a fi introdus în apă, primele diferențe semnificative au apărut la 10 minute de la realizarea detaşării. În cazul transpiraţiei şi conductanței stomatale în situaţia frunzei detaşate, s-au înregistrat diferențe semnificative după 10 , respectiv 13 minute. În ce priveşte parametrii ce caracterizează eficiența utilizării apei (WUE și iWUE), diferențe semnificative din punct de vedere statistic s-au înregistrat după 9 , respectiv 12 minute din momentul întreruperii legăturii dintre frunză și planta mamă. Pentru frunzele atașate de lujerul detaşat, dar neintrodus în apă, transpirația 

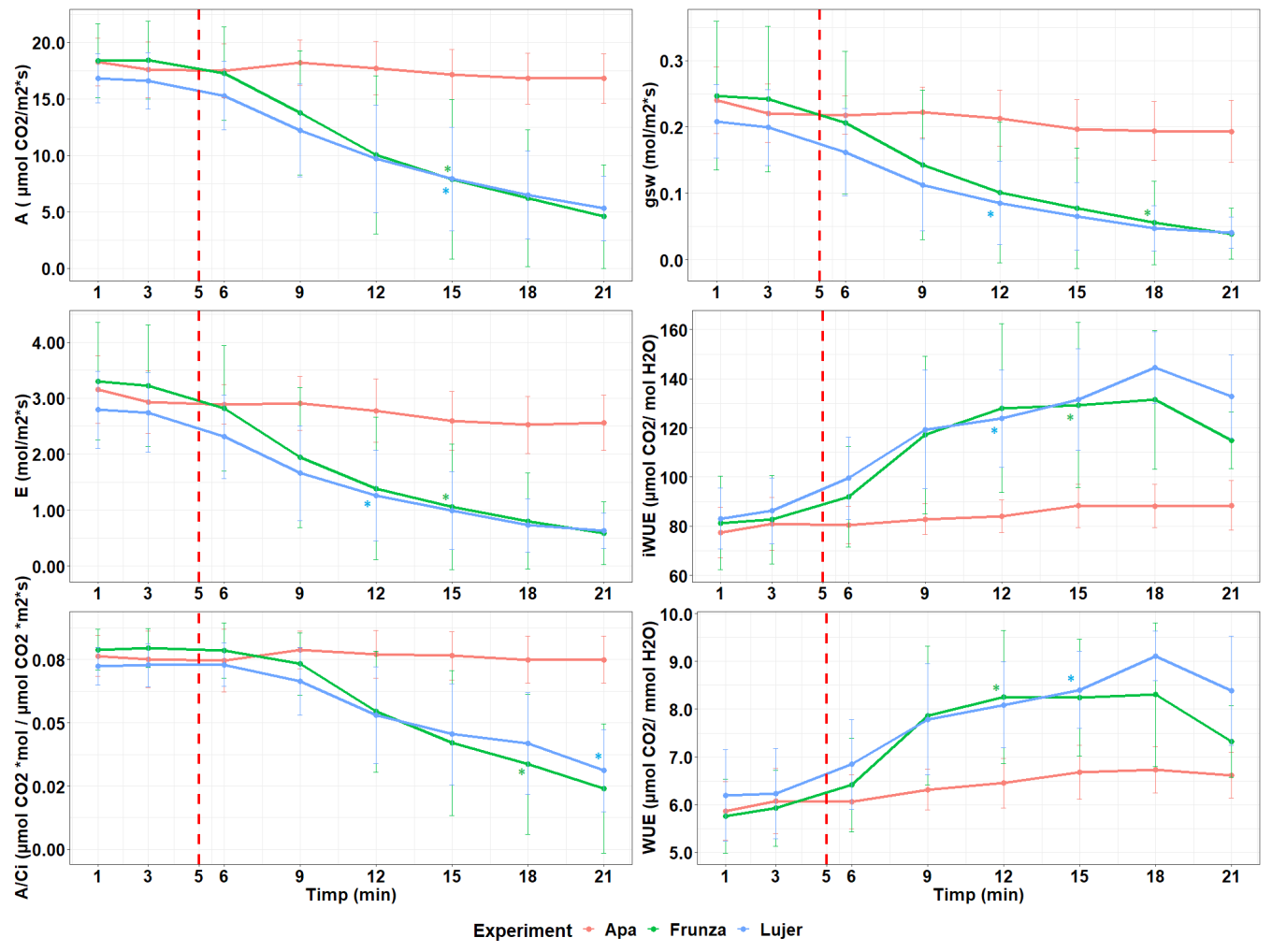

Figura 2 Valorile principalilor parametri de caracterizare a procesului fotosintetic (medie \pm abatere standard) la diferite intervale de timp. Cu asterisc (*) s-a marcat prima valoare care diferă semnificativ față de valoarea de referință considerată (momentul de timp $=1$ minut). Cu linie punctată roșie s-a marcat momentul în care s-a întrerupt legătura frunzei cu planta.

The photosyntesis parameters values (mean \pm standard deviation) at different time intervals. With asterisk (*) was marked the first value that differs significantly from the reference value (time $=1$ minute). The red dotted line marked the moment of leaf detachement.

și conductanța stomatală au înregistrat prima valoare diferită semnificativ faţă de cea de referință la 9 minute.

În urma aplicării testelor statistice s-a constatat faptul că pentru frunzele care au rămas ataşate de lujerul ce a fost introdus într-un recipient cu apă nu sunt modificări semnificative statistic faţă valoarea de referinţă.

\section{Discuții}

Măsurarea capacității fotosintetice pentru speciile lemnoase are o importanță ridicată în înțe- legerea modului în care schimbările climatice afectează productivitatea ecosistemelor forestiere (Lindner et al. 2014), dar și pentru realizarea modelelor de simulare a productivităţii vegetației (Rezende et al. 2016). Majoritatea cercetărilor privind dinamica proceselor fotosintetice au fost realizate in situ și s-au bazat în multe situații pe măsurarea schimbului de gaze la puieți și arbuști, favorizată de înălțimile accesibile (Gallé et al. 2007, Mayoral et al. 2015). Realizarea măsurătorilor privind schimbul de gaze la nivelul coronamentului arborilor nu sunt posibile fără construcții ajutătoare (platforme, scări sau macarale speciale) 
(Gauthier și Jacobs 2018). Soluțiile identificate vizează măsurători pe material biologic detaşat, reprezentând un subiect de cercetare de interes (Tang şi Wang 2011). Implementarea acestor soluții necesită cercetări privind capacitatea frunzei de a-și menține funcțiile fiziologice la nivel comparativ cu cel iniţial, înainte de detaşare (Huang et al. 2009, Gauthier și Jacobs, 2018). Alte soluții vizează măsurarea schimbului de gaze pe frunze a căror pețiol este atașat de un lujer ce a fost prelevat din coronament (Tang și Wang 2011, Meng et al. 2019, Verryckt et al. 2020).

Prin detaşarea frunzei sau lujerului de planta mamă se întrerupe aprovizionarea cu apă și substanțe minerale, respectiv circulația sevei brute. Întreruperea aprovizionării cu sevă brută al ramurilor tăiate produce cavitație și embolie ceea ce reduce capacitatea de transport a apei prin xilem (Meng et al. 2019). Din cauza deficitului de apă din frunză se produce o închidere totală sau parțială a stomatelor și implicit o reducere a transpirației (Boyle et al. 2016). În același timp are loc o scădere a absorbției de $\mathrm{CO}_{2}$, a concentraţiei de $\mathrm{CO}_{2}$ la nivelul spatiilor intercelulare ale mezofilului foliar (Ci) și implicit a ratei asimilației (Lawlor și Cornic 2002). Pentru a evita aceste efecte negative este necesar să se asigure continuitatea fluxului de sevă brută, prin aprovizionarea continuă cu apă (Meng et al. 2019). Rezultatele obținute cât și cercetările similare din literatură au arătat că varianta cea mai bună pentru realizarea măsurătorilor privind schimbul de gaze este prin folosirea de lujeri detaşaţi introduși în apă. Au fost testate diferite variante prin care se poate asigura cea mai bună aprovizionare cu apă în cazul lujerilor detașați: îndepărtarea scoarței pe o lungime de 3 centimetri de la tăietură, ruperea frunzelor care nu fac obiectul studiului (Tang și Wang 2011) sau tăierea oblică, respectiv crăparea lujerului pe o lungime de 3 centimetri (Meng et al. 2019).

Aninul verde este o specie cu o importanță majoră în ecosistemele alpine şi subalpine (Boscutti et al. 2014), vegetând în staţiuni greu accesibile (pantă mare, teren accidentat), limi- tând posibilitatea realizării studiilor de fiziologie. O posibilă soluție pentru intensificarea cercetărilor fiziologice la această specie o reprezintă realizarea măsurătorilor privind capacitatea fotosintetică pe material biologic detașat. Rezultatele obținute au evidențiat scăderi ale asimilației nete imediat după secționarea pețiolului, cu diferențe semnificative statistic după 10 minute de la secționare.

Este cunoscut faptul că există diferențe între modul de modificare a fotosintezei frunzei ca urmare a secționării pețiolului în funcție de specie (Verryckt et al. 2020). Pentru specii de stejar s-au înregistrat tendinţe similare de scădere a asimilației nete cu diferențe semnificative statistic după 6 minute pentru Quercus rubra și 3 minute pentru Q. alba (Gauthier și Jacobs 2018). Întreruperea legăturii dintre frunză și plantă determină o scădere rapidă a conductanței stomatale și transpirației atât pentru aninul verde cât și pentru alte specii, temperatura fiind un factor important (Huang et al. 2009).

Cercetările experimentale realizate au evidenţiat că pentru anumite specii tropicale de arbori asimilația netă rămâne la o valoare de peste $85 \%$ până la o oră după ce s-a întrerupt legătura cu planta mamă (Santiago şi Mulkey 2003). În cazul altor specii arboricole s-au observat diferențe semnificative între valorile măsurate in vivo și valorile măsurate pentru lujeri detaşaţi de planta mamă şi introduși în apă în funcție de modul de realizare a secționării (taiere oblică, realizarea unei crăpături la baza tăieturii, cojirea scoarței în prelungirea tăieturii sau introducerea în acid salicilic) (Meng et al. 2019).

\section{Concluzii}

Dificultatea realizării măsurătorilor privind schimbul de gaze din cadrul proceselor fotosintetice la nivelul coronamentului arborilor sau în staţiuni extreme din punct de vedere al accesibilității impune găsirea unor soluții care să înlăture limitările logistice. În urma cercetă- 
rilor realizate s-a evidențiat faptul că detașarea unei frunze individuale sau a unui lujer fără introducerea acestuia în apă induce modificări fiziologice imediate, cu impact semnificativ asupra fotosintezei și nu se poate asigura comparabilitatea valorilor măsurare cu cele de la frunze nedetaşate. Soluția optimă, în cazul aninului verde, este utilizarea materialului biologic detaşat reprezentat de lujer, cu lungime de 20 centimetri, secționat și introdus imediat într-un recipient cu apă în vederea limitării apariției unui deficit de apă la nivelul frunzei. În acest caz parametrii de caracterizare a procesului de fotosinteză s-au menținut la valori de peste $80 \%$ față de valoarea de referință pentru o perioadă de până la 50 minute. Pentru fundamentarea și generalizarea concluziilor obținute este necesar să se mărească eșantionul analizat și să fie luate în studiu și alte specii.

\section{Mulțumiri}

Pe această cale adresez mulțumiri administrației Parcului Național Călimani pentru permisiunea realizării lucrărilor de teren. De asemenea, mulțumesc doamnei conferențiar universitar doctor Margareta Grudnicki și domnului cercetător științific grad I Ionel Popa pentru îndrumarea și recomandările transmise de-a lungul elaborării acestui studiu.

\section{Bibliografie}

Abdi H., Williams L. J., 1993. Newman-Keuls Test and Tukey Test. Pitman's Measure of Closeness: pp. 101134. doi: 10.1137/1.9781611971576.ch4.

Anthelme F., Cornillon L., Brun J.J., 2002. Secondary succession of Alnus viridis (Chaix) DC. in Vanoise National Park, France: coexistence of sexual and vegetative strategies. Annals of forest science, 59(4): pp.419-428.

Boscutti F., Poldini L., Buccheri M., 2014. Green alder communities in the Alps: Phytosociological variability and ecological features. Plant Biosystems 148(5): pp. 917-934. doi: 10.1080/11263504.2013.809813.

Boyle R. K. A., Mcainsh M., Dodd I. C., 2016. Stomatal closure of Pelargonium $\times$ hortorum in response to soil water deficit is associated with decreased leaf water potential only under rapid soil drying. Physiologia Planta- rum 156(1): pp. 84-96. doi: 10.1111/ppl.12346.

Cavaleri M.A., Reed S.C., Smith W.K., Wood T.E., 2015. Urgent need for warming experiments in tropical forests. Global Change Biology. John Wiley \& Sons, Ltd, 21(6): pp. 2111-2121. doi: 10.1111/gcb.12860.

Covshoff S., 2018. Photosynthesis Methods and Protocols, Methods in Molecular Biology: pp. 346. doi: 10.1007/978-1-4939-7786-4 20.

Gallé A., Haldimann P., Feller U., 2007. Photosynthetic performance and water relations in young pubescent oak (Quercus pubescens) trees during drought stress and recovery. New Phytologist 174(4): pp. 799-810. doi: 10.1111/j.1469-8137.2007.02047.x.

Gauthier M. M., Jacobs D. F., 2018. Reductions in net photosynthesis and stomatal conductance vary with time since leaf detachment in three deciduous angiosperms. Trees - Structure and Function, Springer Berlin Heidelberg 32(5): pp. 1247-1252. doi: 10.1007/ s00468-018-1706-Z.

Huang Y., Mo L., Zhao P., Zhang Z., He C., 2009. Comparison of gas exchanges between in situ and abscised leaves of high arbor trees: A case study of Cylobalanopsis glauca under three habitats. Frontiers of Forestry in China 4(4): pp. 464-471. doi: 10.1007/s11461-0090065-8.

Lawlor D. W., Cornic G., 2002. Photosynthetic carbon assimilation and associated metabolism in relation to water deficits in higher plants. Plant, Cell and Environment 25: pp. 275-294. doi: 10.1046/j.00168025.2001.00814.x.

Lindner M., Fitzgerald J. B., Zimmermann N. E., Reyer C., Delzon S. van der Maaten E., Schelhaas M. J., Lasch P., Eggers J., Marieke van der Maaten-Theunissen, Suckow F., Psomas A., Poulter B., Hanewinkel M., 2014. Climate change and European forests: What do we know, what are the uncertainties, and what are the implications for forest management? Journal of Environmental Management. Elsevier Ltd 146: pp. 69-83. doi: 10.1016/j.jenvman.2014.07.030.

Marozas V., Algirdas A., Ainis P., 2019. Comparative analyses of gas exchange characteristics and chlorophyll fluorescence of three dominant tree species during the vegetation season in hemi-boreal zone, Lithuania. Journal of Agricultural Meteorology, 75(1): pp. 3-12. doi: 10.2480/agrmet.D-18-00004.

Mayoral C., Calama R., Sánchez-González M., Pardos M., 2015. Modelling the influence of light, water and temperature on photosynthesis in young trees of mixed Mediterranean forests. New Forests 46(4): pp. 485506. doi: 10.1007/s11056-015-9471-y.

Meng C., Liu X., Chai Y., Xu J., Yue M., 2019. Another choice for measuring tree photosynthesis in vitro. PeerJ 2019(1). doi: 10.7717/peerj.5933.

Meng F. R., Arp P., 1992. Net photosynthesis and stomatal conductance of red spruce twings before and after twig detachment. Can. J. For. Res. 23: pp. 716-721.

Mitchell K. A., Bolstad P. V., Vose J. M.,1999. Interspecific and environmentally induced variation in foliar dark 
respiration among eighteen southeastern deciduous tree species. Tree Physiology 19(13): pp. 861-870. doi: 10.1093/treephys/19.13.861.

Nakamura A., Kitching R. L., Cao M., Creedy T. J., Fayle T. M., Freiberg M., Hewitt C. N., Itioka T., Koh L. P., Ma K., Malhi Y., Mitchell A., Novotny V., Ozann, C. M. P., Song L., Wang H., Ashton L. A., 2017. Forests and Their Canopies: Achievements and Horizons in Canopy Science.Trends in Ecology and Evolution. Elsevier Ltd 32(6): pp. 438-451. doi: 10.1016/j.tree.2017.02.020.

Pallardy, S., 2008, Physiology of Woody Plants: pp. 496 doi: $10.1071 /$ pc980272.

Rezende L. F. C., Arenque B. C., Aidar S. T., Moura M. S. B., Von Randow C., Tourigny E., Menezes R. S. C., Ometto J. P. H. B., 2016. Evolution and challenges of dynamic global vegetation models for some aspects of plant physiology and elevated atmospheric $\mathrm{CO}_{2}$. Inter- national Journal of Biometeorology 60(7): pp. 945-955. doi: 10.1007/s00484-015-1087-6.

Santiago L. S., Mulkey S. S., 2003. A test of gas exchange measurements on excised canopy branches of ten tropical tree species. Photosynthetica 41(3): pp. 343-347. doi: 10.1023/B:PHOT.0000015457.92479.eb.

Tang Y., Wang C.K., 2011. A feasible method for measuring photosynthesis in vitro for major tree species in northeastern China. Chinese Journal of Plant Ecology 35(4): pp. 452-462. doi: 10.3724/sp.j.1258.2011.00452.

Verryckt L. T., Van Langenhove L., Ciais P., Courtois E. A., Vicca S., Peñuelas J., Stahl C., Coste S., Ellsworth D. S., Posada J. M., Obersteiner M., Chave J., Janssens I. A., 2020. Coping with branch excision when measuring leaf net photosynthetic rates in a lowland tropical forest. Biotropica 52(4): pp. 608-615. doi: 10.1111/ btp. 12774 . 